\title{
A Mediação Pedagógica de uma Licencianda em Ciências Biológicas em uma Aula Investigativa de Ciências Envolvendo Conceitos Físicos
}

\section{The Pedagogical Mediation Performed by a Graduate Student in Biological Sciences in an Inquiry-Based Science Classe Involving Physics Concepts}

\author{
Leandro da Silva Barcellos Brasil \\ Suiany Vitorino Gervásio ${ }^{\text {(1) }}$ Brasil \\ Mirian do Amaral Jonis Silva ${ }^{(10)}$ Brasil \\ Geide Rosa Coelho ${ }^{(1)}$ Brasil
}

Esta pesquisa tem como objetivo analisar a mediação pedagógica realizada por uma graduanda em Ciências Biológicas durante uma aula de Ciências baseada no ensino por investigação que envolveu conceitos científicos de Física. A pesquisa, de cunho qualitativo e do tipo intervenção, utilizou como fonte de dados as interações discursivas entre professora e estudantes em uma turma de sexto ano do ensino fundamental de uma escola da rede municipal de Vitória, no Espírito Santo, coletadas através de registros de áudio. A análise da mediação realizada pela licencianda apoiou-se na teoria da ação mediada de Wertsch, enquanto o processo de enculturação foi investigado sob a luz da matriz sociocultural. Os resultados ajudam a entender a intrínseca relação entre a mediação intencional e organizada e a promoção de um ambiente investigativo, rico em trocas verbais, as quais contribuíram com o processo de enculturação dos estudantes.

Palavras-chave: formação do professor de Ciências; ação mediada; ensino por investigação; enculturação científica; ensino de conceitos físicos.

This research aims to analyze the pedagogical mediation performed by a graduate student of Biological Sciences during a science lesson oriented on inquiry-based teaching that involved scientific concepts of physics. It is a qualitative intervention research, which used the discursive interactions between teacher and pupils in the sixth year of primary education in a public school in Vitória, Espírito Santo, collected as audio recordings. The analysis of the mediation carried out by the graduate student relied on Wertsch's theory of mediated action, and the scientific enculturation process has been investigated under the light of sociocultural matrix. The results help us to understand the intrinsic relation between an intentional and organized mediated action and the availability of a rich verbal interaction in an inquiry-based environment that contributed to process of 
scientific enculturation of students.

Keywords: science teacher formation; mediated action; inquiry-based teaching; scientific enculturation; teaching physics concepts.

\section{Introdução}

A disciplina Ciências nos anos finais do ensino fundamental é conduzida, a princípio, por professores com formação inicial em Ciências Biológicas. A disciplina Ciências envolve conhecimentos relativos à Física, à Química e à Biologia, e, por isso, deve ter seus conteúdos de ensino abordados de forma articulada.

Para Aguiar Júnior e Lima (1999) é fácil estabelecer um perfil básico para a realidade do ensino de Ciências nos anos finais do ensino fundamental: as disciplinas são compartimentadas e sobrecarregadas de informações que pouco contribuem para o desenvolvimento de competências sociais nos estudantes; as aulas são centradas no professor, que as conduz de maneira expositiva, organizadas em torno dos saberes biológicos; os conteúdos de Física e Química são deixados para o nono ano, sob a alegação de que seriam uma preparação para o ensino médio. Os mesmos autores destacam que "as lacunas são particularmente evidentes no que se refere ao conhecimento físico e químico e nos levam a tecer considerações sobre a formação inicial de professores de ciências para esse nível de ensino" (Aguiar Junior, \& Lima, 1999, p. 2).

Cunha e Krasilchik (2000) afirmam que as licenciaturas em Ciências Biológicas não formam de maneira satisfatória o professor para o ensino de Ciências no ensino fundamental, incluindo os cursos mais bem conceituados e os vinculados ao bacharelado. Ampliando um pouco mais essa discussão, Bertagna-Rocha (2013) sinaliza que os professores de Ciências são formados em uma perspectiva conteudista, fragmentada e dissociada da realidade das salas de aula, o que pouco contribui para que eles possam trabalhar com os estudantes da educação básica o desenvolvimento de uma postura crítico-reflexiva.

Carvalho e Gil-Pérez (2011) nos dizem que a formação de professores de Ciências no Brasil anseia por inovações e reestruturações há pelo menos uma década. Os autores destacam duas demandas formativas para professores de Ciências: conhecer a matéria a ser ensinada e saber preparar atividades capazes de gerar uma aprendizagem efetiva. Sobre a primeira, é praticamente um consenso entre os profissionais da Educação a necessidade do domínio do conteúdo a ser trabalhado. Contudo, os mesmos autores alertam para pesquisas que revelam a carência de conhecimentos tanto por parte dos professores generalistas como também dos especialistas, o que, segundo eles, pode resultar em um ensino transmissivo e mecânico dos conteúdos do livro didático. Em relação à segunda demanda destaca-se:

O interesse por saber organizar atividades de aprendizagem manifesta-se como uma das necessidades formativas básicas dos professores. Inclusive aqueles que orientam o seu ensino como uma transmissão de conhecimentos já elaborados, consideram muito 
conveniente poder completar suas explicações com algum tipo de atividade dos alunos. Esse interesse cresce, é lógico, quando se pretende organizar a aprendizagem como uma construção de conhecimentos por parte dos alunos (Carvalho, \& Gil-Perez, 2011, p. 43).

Em um cenário sócio-educacional em que se espera que os professores não sejam apenas transmissores de conteúdos, é importante problematizar a formação dos licenciados em Ciências Biológicas. Estariam esses futuros profissionais preparados para abordar conceitos físicos, químicos e biológicos de forma integrada e articulada no ensino fundamental? Assim, investigar o modo como lidam com esses desafios, quer seja durante a formação, quer seja no exercício da profissão docente, é de fundamental importância para que possam ser estabelecidos planos de ação que contribuam com as demandas atuais da educação em ciências.

Esta pesquisa investiga um contexto real de sala de aula da educação básica, tendo como objetivo analisar a mediação pedagógica realizada por uma graduanda em Ciências Biológicas durante uma aula de Ciências baseada no ensino por investigação que envolveu conceitos físicos, em uma turma do sexto ano do ensino fundamental de uma escola da rede municipal de Vitória, no Espírito Santo. Buscamos indícios que nos permitissem entender se a mediação promovida pela licencianda em sala de aula contribuiu para o estabelecimento de um ambiente investigativo. Para isso, nos apoiamos na teoria da ação mediada de Wertsch, buscando compreender como as interações entre eles e deles com as ferramentas socioculturais medeiam os processos de formação de conceitos e enculturação científica.

\section{Fundamentação teórica}

\section{Ensino por investigação e o processo de enculturação dos estudantes}

Barrow (2006) menciona as diferentes definições trazidas pela literatura - e também pela gramática - ao ensino por investigação. Considerando a polissemia associada a essa abordagem, podemos dizer que existem diferentes possibilidades para o ensino por meio de atividades investigativas. Mesmo não havendo uma unanimidade entre os pesquisadores da área, há diversos pontos comuns com relação ao ambiente de ensino organizado por essa perspectiva. Sá, Paula, Lima e Aguiar (2007) e Azevedo (2004) concordam que uma atividade investigativa inicia-se com a proposição de uma situação-problema que permita a elaboração e teste de hipóteses, a coleta e análise de dados, debate a partir de múltiplas interpretações e a comunicação de resultados, sempre atuando em parceria com o professor. Os autores destacam que, ao realizar esses procedimentos, os estudantes se aproximam da investigação científica autêntica.

Duschl (1994) afirma que os estudantes devem adotar procedimentos similares aos que os cientistas adotam para investigar situações-problema em aulas de ciências, visando a aquisição de conhecimentos. Assim, a mudança ocorre tanto nas ações quanto no planejamento, o qual precisa partir de uma problematização adequada, que possibilite a criação do ambiente investigativo. Isso significa que o problema deve ser claro, bem 
delimitado, atrelado ao novo conceito a ser trabalhado e, se possível, conectado a alguma aplicação cotidiana ou vivência dos estudantes.

No ensino por investigação, as atividades devem ser centradas nos alunos, de modo que eles possam ir além do trabalho de manipulação ou observação, desenvolvendo ações que os levem a questionar, argumentar e organizar suas ideias. Existem diferentes possibilidades para o ensino por meio de atividades investigativas, "por exemplo: laboratório aberto, demonstração investigativa, textos históricos, problemas e questões abertas, recursos tecnológicos" (Carvalho, 2018, p. 767). Apesar da polissemia associada à compreensão do ensino por investigação e das diferentes configurações de atividades, é consenso entre os diferentes pesquisadores que as ações desenvolvidas nessa abordagem estão atreladas à proposição de situações-problema.

Para Sasseron (2015) a abordagem investigativa em aulas de ciências pode atuar como um facilitador de aspectos importantes para o ensino, possibilitando aos alunos condições para a resolução de problemas e o estabelecimento de relações causais para explicar o fenômeno estudado. Isso acontece por meio da formulação e teste de hipóteses, culminando na construção de modelos explicativos e na socialização dos resultados obtidos.

Nessa perspectiva, o docente se torna responsável por fomentar os debates enriquecendo-os com novas questões e discussões, conduzindo e auxiliando os estudantes no processo de ressignificação dos conceitos compartilhados na sala de aula, tendo em vista o desenvolvimento da autonomia de pensamento por parte dos discentes (Azevedo, 2004).

Borges (2002) sinaliza que professores da educação básica concordam com o fato de a melhoria no ensino de Ciências estar associada à inclusão de aulas práticas nos currículos. Porém, quando as aulas prático-experimentais são realizadas na escola, normalmente são desenvolvidas na forma de laboratório tradicional, caracterizada pela realização de atividades práticas envolvendo observação e medidas por parte dos estudantes, quase sempre com resultados previamente determinados pelo professor, o que aponta para um modelo verificacionista de Ciência.

Neste sentido, Hodson (1988) afirma que essa abordagem didática é questionável, dado que ela sugere uma visão do conhecimento científico como algo previsível, imutável, inegociável e não problemático, além de centralizar as ações no professor, que as protagoniza juntamente com os discursos da aula, atribuindo-lhe um papel de fonte de conhecimento. Por isso, para Borges (2002) as práticas laboratoriais na escola podem e devem ter um papel mais relevante no processo de ensino e aprendizagem em Ciências. Um importante passo nessa direção é buscar novas maneiras de desenvolver atividades prático-experimentais com propósitos bem definidos e com criatividade, como na perspectiva do laboratório investigativo, em que a estruturação das atividades laboratoriais são pensadas como investigações ou problemas práticos abertos. Os problemas abertos são caracterizados por não possuírem uma solução imediata obtida por meio da aplicação de fórmulas. Ao contrário, exigem a elaboração de hipóteses, 
testes e reflexões menos estruturadas.

Assim, na abordagem investigativa o estudante passa a ser protagonista das ações e tem papel fundamental na construção do conhecimento. Se o ensino por investigação propõe uma mudança de atitude dos estudantes, é de se esperar que implique em uma mudança na atitude docente. Se o estudante protagonizará as ações, o professor deve assumir um papel mediador por meio do trabalho colaborativo assumido coletivamente em sala de aula, de modo que todos tenham incumbências no processo de apropriação dos saberes (Sá et al., 2007). Assim, a mediação adotada pelo professor terá um papel fundamental na promoção de um ambiente propício a interações e trocas verbais na busca pela solução do problema.

Considerando que os avanços das ciências da natureza estão correlacionados a aspectos de ordem social, histórica e cultural, assim como qualquer outro empreendimento humano, "podemos conceber a cultura científica como o conjunto de ações e de comportamentos envolvidos na atividade de investigação e divulgação de um novo conhecimento sobre o mundo natural" (Sasseron, 2015, p. 55). Entender o conhecimento científico como uma construção social traz implicações diretas para a educação em ciências, entre elas a necessidade de iniciação dos estudantes nas formas científicas de pensar, fazer e agir, a fim de que possam compreender como as ideias científicas são construídas, validadas e divulgadas por meio das instituições culturais de ciências (Sasseron, 2018).

Driver, Asoko, Leach, Mortimer e Scott (1999) nos dizem que a aprendizagem em Ciências está relacionada à iniciação dos estudantes nas ideias e práticas da comunidade científica. Então, podemos entender a aprendizagem em Ciências como sendo um processo de introdução dos estudantes na cultura das Ciências. Na busca para se obter o processo de enculturação, o professor precisa disponibilizar para os alunos as ferramentas culturais da comunidade científica, conduzindo-os no processo de apropriação dos modelos, reconhecimento de seus domínios e aplicabilidades para que eles sejam capazes de utilizá-los.

Parte-se do princípio de que os estudantes podem ser inseridos na cultura científica quando se depararem com situações-problema nas quais o conhecimento científico é requerido e avaliado na busca pela solução. Logo, assumir o ensino por investigação como perspectiva para as aulas de Ciências pode potencializar o processo de enculturação, visto que essa abordagem promove aprendizagem em Ciências a partir da vivência do trabalho científico dos estudantes (Ainkenhead, 2009; Driver et al. 1999). Ou, ainda, como afirmam Trivelato e Tonidandel (2015, p. 102-103):

Uma característica marcante nas atividades investigativas é a preocupação com o processo de aprendizagem dos estudantes, que têm seu foco deslocado da aquisição de conteúdos científicos para a sua inserção na cultura científica e para o desenvolvimento de habilidades que são próximas do "fazer científico". É importante que, além dos aspectos relacionados aos procedimentos como observação, manipulação de materiais de laboratório e experimentação, as atividades investigativas incluam a motivação e o 
estímulo para refletir, discutir, explicar e relatar, o que promoverá as características de uma investigação científica.

A familiarização dos estudantes com essa nova cultura envolve a apropriação de conceitos, o desenvolvimento de atitudes e procedimentos por meio das interações sociais na sala de aula.

Pozo e Gómez-Crespo (2009) ressaltam que não há consonância na definição dos conteúdos procedimentais, mas afirmam que eles estão atrelados às estratégias e técnicas adotadas pelos alunos para solucionar os problemas estudados, bem como o saber fazer adquirido através de ações práticas. Os conteúdos procedimentais podem ser vistos nos demais conteúdos, mas possuem muitas peculiaridades. No contexto do ensino por investigação, esses procedimentos estão relacionados ao "trabalho com dados, informações e conhecimentos já existentes, o levantamento e o teste de hipóteses, o reconhecimento de variáveis e o controle das mesmas, o estabelecimento de relações entre informações e a construção de uma explicação" (Sasseron, 2013, p. 43).

Pozo e Gómez-Crespo (2009) assinalam que a elaboração de um currículo que contemple também os conteúdos atitudinais, requer que os professores tomem consciência das atitudes que almejam desenvolver com seus alunos, bem como aquelas que expressam em suas práticas. Estamos demarcando desse modo a importância do engajamento dos estudantes no trabalho colaborativo perpassado pelas interações dialógicas para construção do conhecimento científico e para o desenvolvimento de um posicionamento crítico e reflexivo com relação a diversos temas de relevância social.

\section{Ação mediada: um referencial para analisar a postura pedagógica do professor em aulas de Ciências}

Carvalho (2013) estabelece uma interlocução com as ideias de Vigotski ao destacar que as interações sociais são mediadas pela utilização de ferramentas ou artefatos culturais, como a linguagem, considerada a mais importante entre elas.
(...) a linguagem das Ciências não é só uma linguagem verbal. As Ciências necessitam para expressar suas construções, de figuras, tabelas, gráficos e até mesmo da linguagem matemática. Portanto, temos de prestar atenção nas outras linguagens, uma vez que somente as linguagens verbais - oral e escrita - não são suficientes para comunicar o conhecimento científico. Temos de integrar, de maneira coerente, todas as linguagens, introduzindo os alunos nos diferentes modos de comunicação que cada uma das disciplinas utiliza, além da linguagem verbal, para a construção de seu conhecimento (Carvalho, 2013, p. 6).

Carvalho (2013) destaca ainda que uma aula baseada no ensino por investigação é um ambiente adequado para a promoção de interações discursivas, uma vez que o processo de resolução de um problema permite o surgimento de diferentes soluções elaboradas pelos estudantes. Portanto, o conhecimento é construído através do engajamento social desses sujeitos em situações-problema e conversações. À medida em que isso acontece, ocorre à apropriação das ferramentas culturais, haja vista a natureza 
dialógica do processo de construção de significados.

Pereira e Ostermann (2012) compartilham da mesma perspectiva recorrendo à teoria de Wertsch. Com base nesse autor, afirmam que todas as ferramentas culturais são materiais, incluindo os meios mediacionais semióticos, como a linguagem. Reconhecer isso significa dizer que as ferramentas culturais podem causar modificações nos agentes, e à medida que estes atuam com as propriedades das ferramentas, ocorre $\mathrm{o}$ desenvolvimento de habilidades para lidar com elas.

Diante desse cenário, consideramos pertinente investigar a ação mediada em uma aula de ciências com enfoque no ensino por investigação, uma vez que, a postura assumida pelo docente nessa abordagem também lhe incumbe de utilizar ferramentas culturais para mediar o processo de construção de conhecimento científico dos estudantes, potencializando o desenvolvimento de competências típicas da cultura científica escolar (Ferraz, \& Sasseron, 2017).

Trazzi e Oliveira (2016) nos dizem que investigar o contexto em que os discursos são produzidos é primordial para a educação científica. Assim, a teoria da ação mediada de Wertsch (1999) nos ajuda a caracterizar a postura assumida pelo professor, dado que ela contempla o contexto no qual as ações humanas e mediações se desenvolvem.

Pereira e Ostermann (2012) reconhecem que a ação mediada é a unidade de análise ideal para o estudo do funcionamento humano, visto que todas as ações empregam ferramentas culturais disponíveis em determinados contextos socioculturais. A compreensão de um contexto envolve cinco termos: (i) ato (ação), que se refere a o que ocorreu na ação ou no pensamento; (ii) cena (contexto), que representa a situação em que ocorreu; (iii) agente, que é o sujeito que realiza a ação ou o pensamento; (iv) propósito, que sinaliza para a intenção do agente; e (v) agência, que são as ferramentas socioculturais utilizadas (Wertsch, 1999).

Pereira e Ostermann (2012) apoiados em Wertsch (1998), consideram que a ação mediada possui uma "tensão irredutível" entre os agentes e as ferramentas culturais que eles utilizam o que nos leva a ir além do agente individual para elucidar as forças que caracterizam as ações humanas. Wertsch (1999) aponta que a ação mediada deve priorizar os agentes e as agências, pois entendê-los auxiliaria no processo de compreensão do ato, cena e propósito. $\mathrm{O}$ autor considera que toda ação humana é uma ação mediada, logo, defini-la de forma precisa seria uma tarefa árdua. No ambiente escolar, a ação mediada está relacionada com as diversas ações instituídas que devem favorecer o aprendizado dos estudantes, entre elas a linguagem e o discurso, protagonizados por docentes e discentes, o que ratifica o caráter discursivo dessa interação. Para Wertsch (1999), a linguagem é uma ferramenta sociocultural e o discurso uma forma de ação mediada. Em vista disso, entendemos que a linguagem e seu contexto são fundamentais no processo de ensinoaprendizagem.

Ao caracterizar a mediação do professor durante a condução de uma aula baseada no ensino por investigação, estamos destacando a maneira como ele conduz as interações entre os sujeitos de sala de aula na busca pela criação de um ambiente investigativo, 
retirando o foco do experimento por si só, visto que algumas vezes essa abordagem é entendida como sinônimo de atividade experimental em que o estudante simplesmente "põe a mão na massa". Porquanto, recorremos à teoria da ação mediada de Wertsch para caracterizar a mediação adotada pela licencianda durante a aula investigativa, com o intuito de entendermos as estratégias utilizadas, os recursos e a forma como as interações foram estabelecidas entre os sujeitos de sala de aula na busca pela criação de um ambiente investigativo. Nesse sentido, Pereira e Ostermann (2012) consideram que a compreensão dos discursos de sala de aula pode ser a chave para a compreensão dos efeitos de abordagens ou metodologias no processo de ensino e aprendizagem.

Assim, ao concebermos o ensino por investigação como uma postura pedagógica a ser assumida, e não como um método a ser aplicado, estamos destacando a importância da mediação do professor, pois, uma mediação balizada por uma situação-problema adequada e relevante para os alunos possibilita a criação de um ambiente investigativo em sala de aula, tornando-a um espaço no qual os estudantes podem compartilhar experiências, informações e conhecimentos uns com os outros e com o professor, rico em diálogos, debates e discussões, potencializando o desenvolvimento não apenas de conceitos, mas também de atitudes e procedimentos típicos da ciência escolar, promovendo a introdução dos estudantes na cultura científica. Dessa forma, o professor assume a postura que, segundo Carvalho e Gil-Pérez (2011), assemelha-se ao papel de um pesquisador mais experiente orientando pesquisadores iniciantes.

O processo de enculturação dos estudantes em práticas típicas da cultura científica envolve o engajamento em diferentes formas de ação humana, a saber: observar, descrever, comparar, classificar, analisar, questionar, argumentar, planejar, avaliar, generalizar, entre outras. Nesse sentido, Pereira e Ostermann (2012) afirmam que, para Wertsch, o desenvolvimento de determinadas habilidades específicas surge da experiência. O ensino de Ciências deve, portanto, criar oportunidades para que os estudantes atuem com essas ferramentas, permitindo-lhes tomar consciência sobre seus usos e, assim, identificar e modificar as formas de mediação indesejáveis. Isso porque, “a percepção de que novas ferramentas culturais transformam a ação mediada e o entendimento de como essas transformações ocorrem é fundamental para o processo de domínio e apropriação por parte dos estudantes" (Pereira, \& Ostermann, 2012, p. 36).

Assumir o ensino por investigação como abordagem para as aulas de Ciências requer uma mudança de postura radical por parte do professor em relação ao ensino tradicional que centraliza os processos educativos em torno do seu discurso. O processo de apropriação dessa abordagem envolve uma análise da própria prática, o que é um elemento importantíssimo no processo de formação inicial de professores (Carvalho, \& Gil-Pérez, 2011). Com base nesses pressupostos, desenvolveu-se uma intervenção pedagógica elaborada por uma professora de Ciências em formação inicial, fundamentada no caráter investigativo para o desenvolvimento das ações propostas, buscando evidenciar o papel mediador do professor, assim como o protagonismo dos estudantes nas interações em sala de aula e o uso das ferramentas mediacionais no 
desenvolvimento dos conceitos científicos abordados.

Nesse sentido, reconhecendo como objetivo central deste estudo a análise da mediação pedagógica de uma graduanda de Ciências Biológicas durante uma aula de Ciências baseada no ensino por investigação envolvendo conhecimentos físicos, nos perguntamos: Como ocorreu a mediação pedagógica na sala de aula, visando o desenvolvimento de conceitos científicos? Quais estratégias foram desenvolvidas pela professora em formação para engajar os estudantes em um processo autêntico de investigação na sala de aula?

\section{Metodologia}

Esta pesquisa se desenvolve no âmbito da disciplina de Pesquisa e Prática Pedagógica (PPP), que é obrigatória na grade curricular do curso de licenciatura em Ciências Biológicas da Universidade Federal do Espírito Santo (UFES). Sua cargahorária é de 60 horas, sendo 15 delas dedicadas à teoria e 45 ao laboratório. No Plano Pedagógico do Curso, elaborado em 2006, é sugerido que essa disciplina seja cursada no quinto período, sem nenhum pré-requisito, sendo-lhe atribuídos dois créditos. Sua ementa é descrita como:

Relação entre a pesquisa, formação do professor e prática pedagógica, com vistas ao ensino com pesquisa, considerando suas diferentes interfaces. Análise crítica da ação docente e o papel do professor na pesquisa, na produção e socialização do conhecimento sobre o ensino. Elementos teórico-metodológicos e diferentes enfoques da pesquisa sobre, com e para a prática pedagógica, com ênfase no ensino de Ciências e Biologia (Projeto Pedagógico do Curso de Ciências Biológicas, 2006).

No contexto da UFES, a disciplina PPP está vinculada ao Laboratório de Educação em Ciências (LabEC) da Universidade Federal do Espírito Santo, que oferece suporte às disciplinas ofertadas para os cursos de Licenciatura em Física, Química, Ciências Biológicas e de Pedagogia relativas ao conteúdo e metodologia das Ciências Naturais. Nessas disciplinas, as atividades são realizadas em uma perspectiva interdisciplinar e fundamentadas no Ensino por Investigação, com o intuito de suscitar, nos futuros professores, reflexões acerca das tendências atuais da atuação docente, cujo objetivo é promover a aprendizagem de Ciências na educação básica a partir da vivência do trabalho científico pelos estudantes (Aikenhead, 2009; Lima, Martins, \& Paula, 2009).

Concordamos com Carvalho e Gil-Perez (2011) quando afirmam que os professores de Ciências precisam aprender sobre as abordagens de ensino no contexto em que elas serão desenvolvidas, assim, o Laboratório de Educação em Ciências mantém os esforços de articular os processos de formação inicial e continuada fundamentados, principalmente no planejamento, implementação de sequências de ensino investigativas (Carvalho, 2013) no cotidiano escolar e analisando os efeitos dessas intervenções sobre diferentes aspectos tanto do ponto de vista da aprendizagem dos estudantes, quanto do ponto de vista formativo desses professores.

Com base nas perspectivas que norteiam o LabEC, a disciplina PPP buscou o 
desenvolvimento de projetos de intervenção no contexto escolar com vistas à inovação de práticas pedagógicas para inserção de abordagens atuais no ensino de ciências. Dentre os projetos desenvolvidos no âmbito da disciplina, destacou-se o interesse de uma das alunas do curso em desenvolver uma sequência de ensino investigativa envolvendo conceitos físicos e biológicos, numa perspectiva interdisciplinar. A proposta deu origem a um projeto de pesquisa que envolveu, em princípio, a própria licencianda, que desenvolveu a intervenção na escola, e a professora responsável pela disciplina PPP. Logo juntaram-se ao projeto um aluno do Programa de Pós-graduação em Ensino de Física que desenvolvia um estudo com temática afim e o seu orientador. A composição desse grupo de pesquisadores foi muito interessante por ser representativa de algumas das aproximações que consideramos desejáveis e necessárias no espaço acadêmico e, sobretudo, na formação de professores: a aproximação entre a universidade e a escola, entre a formação inicial e continuada de professores nos níveis de graduação e pósgraduação e, por fim, a aproximação entre a pesquisa e a prática pedagógica, tendo a reflexão crítica como elemento fundante desse processo.

Descrito todo esse contexto, assumimos o caráter interventivo dessa pesquisa, que emerge como opção metodológica quando o pesquisador planeja e implementa uma interferência com o intuito de promover implicações no processo de ensinoaprendizagem no cotidiano escolar. Posteriormente, os efeitos dessa interferência são analisados (Damiani, Rochefort, Castro, Dariz, \& Pinheiro, 2013). Esse tipo de pesquisa também se caracteriza por ser aplicada e por ser realizada com e sobre pessoas, em ambientes reais.

Buscando resumir e sistematizar essa metodologia de pesquisa, Damiani (2012, p. 7) arrola os seguintes aspectos:

são pesquisas aplicadas, em contraposição a pesquisas fundamentais; (b) partem de uma intenção de mudança ou inovação, constituindo-se, então, em práticas a serem analisadas; (c) trabalham com dados criados, em contraposição a dados já existentes, que são simplesmente coletados; (d) envolvem uma avaliação rigorosa e sistemática dos efeitos de tais práticas, isto é, uma avaliação apoiada em métodos científicos, em contraposição às simples descrições dos efeitos de práticas que visam à mudança ou inovação.

Damiani et al. (2013) dialogam com Robson (1993) para demarcar a importância dessa metodologia como potencializadora dos impactos da pesquisa sobre a prática, em especial quando os próprios professores assumem o papel de investigadores. Em um cenário em que muitos docentes repetem posturas vivenciadas e influenciadas pela formação ambiental ao longo de toda sua formação (no ensino básico e superior), pode ocorrer à naturalização de práticas, as quais muitas vezes ficam isentas de um processo de reflexão. Nesse sentido, os autores novamente recorrem a Robson (1993) para destacar que a pesquisa intervenção pode subsidiar a tomada de decisão sobre mudanças em práticas educacionais, além de promover o aprimoramento e inovações em sistemas de ensino. 
Podemos entender a pesquisa intervenção como um importante elemento a ser explorado na formação inicial docente, estimulando a investigação e reflexão da própria prática a partir de ações concretas planejadas e desenvolvidas pelos licenciandos. Portanto, desenvolver e realizar intervenções possibilita que o graduando vivencie as propostas, analise-as criticamente, potencializando a construção de saberes docentes (Carvalho, \& Gil-Pérez, 2011). Com essa atitude, concordamos com Lüdke, Cruz e Boing (2009) que sinalizam para a importância da pesquisa realizada por professores acerca de sua própria prática pedagógica, constituindo, portanto, estatuto epistemológico da práxis.

A SEI elaborada pela licencianda foi estruturada em três aulas, e abordou o tema microrganismos. Ao propor a análise da intervenção desenvolvida durante a disciplina, buscou-se estimular o processo de pesquisa e reflexão da própria prática, além de possibilitar a vivência de uma experiência envolvendo o ensino por investigação em uma sequência de ensino interdisciplinar, que é a perspectiva teórico-metodológica que fundamenta as ações do Laboratório de Educação em Ciências. Todos esses elementos são pilares desse laboratório, e a inclusão de uma aula com foco em conceitos de óptica geométrica procurou romper com a repetição de duas práticas "consagradas" no ensino fundamental, a saber: o ensino de ciências "biologizado", que, segundo Schroeder (2004), consiste no fato de professores enfatizarem tópicos vinculados à alimentação e higiene em detrimento aos assuntos que possuem maior relação com a Física e a Química; e trabalhar conceitos de Física apenas no nono ano. Essas características apontam para o entendimento de pesquisa intervenção apresentado por Damiani et al. (2013), por permitir a proposição, vivência e análise de práticas inovadoras, possibilitando a produção de conhecimento docente.

Todas as aulas da SEI basearam-se no experimento conhecido como microscópio de gota, que permite a ampliação de uma gota de água, e consequentemente, a visualização de alguns seres microscópicos. O experimento envolve os seguintes materiais: caneta laser verde, seringa descartável, suportes e amostras de água. A montagem consiste em: (a) coletar amostras de água que se queira investigar; (b) pegar a água com a seringa e apoiá-la sobre suportes (podem ser copos ou até mesmo livros); (c) pressionar levemente o êmbolo para que uma gota fique presa à ponta da seringa. (d) escurecer o ambiente onde a atividade será realizada; (e) disparar o laser no centro da gota, em direção a um anteparo branco.

A primeira aula da SEI objetivava levar os alunos a compreender o funcionamento do microscópio de gota como instrumento óptico de ampliação e entender a gota de água como um ambiente de diversidade biológica. Os objetivos da segunda aula foram: Compreender os diferentes fatores que tornam a água imprópria para uso ou consumo. A terceira e ultima aula teve como objetivos entender a importância da higiene das mãos e compreender os perigos do consumo de água não tratada.

A SEI foi desenvolvida em uma turma de sexto ano do ensino fundamental em uma escola da rede municipal de Vitória, no Espírito Santo. A intervenção ocorreu 
no segundo semestre do ano de 2017 e envolveu 38 estudantes. Todas as atividades desenvolvidas na escola foram devidamente autorizadas por todos os participantes, resguardando-se o sigilo dos registros e o anonimato dos sujeitos. A fim de preservar a identidade dos participantes, empregamos nomes fictícios para designar todos os sujeitos envolvidos e, daqui em diante, utilizamos o pseudônimo Silvia para nos referirmos à licencianda que conduziu a intervenção.

Para este artigo, foram consideradas as análises da primeira aula da SEI, pois foi o momento em que emergiram as discussões relacionadas aos aspectos físicos.

Embora a escola possua laboratório de Ciências, a atividade foi realizada no auditório por ser um espaço mais amplo e por oferecer melhores condições para o escurecimento do ambiente, que se fez necessário para a projeção das imagens do microscópio de gota. Os estudantes foram encaminhados até o local e lá foram recepcionados por Silvia.

A interação dialógica entre os sujeitos de sala de aula foi o eixo central para a análise da ação mediada e o processo de enculturação dos estudantes. Atentamo-nos aos momentos em que as discussões envolviam fenômenos relacionados à óptica geométrica para selecionar o que Carvalho et al. (1993) denominam de "episódios de ensino", que consistem em momentos específicos de uma aula que são explicitadas uma situação que deseja-se investigar.

Essas situações, que se relacionam com as perguntas do pesquisador, pode ser, por exemplo, a participação dos alunos levantando hipóteses durante a resolução de um problema experimental, a argumentação que aparece em um debate entre professor e alunos, os tipos de perguntas que os professores fazem para seus alunos, as seqüências das explicações dos alunos durante uma experiência, as discussões dos alunos após a leitura de um texto de história das ciências, etc. (Carvalho, 2004, p.8).

É importante destacar que os eventos de uma sala de aula não ocorrem de maneira linear. O processo de tomada de consciência e de construção do conhecimento envolve idas e vindas a partir de diferentes interações. Logo, um episódio de ensino não precisa ser necessariamente contínuo, ou seja, ele pode ser interrompido e retomado em outro momento. Nesse caso, cabe ao pesquisador construir o episódio a partir desses diferentes momentos, como se fosse a montagem de um filme em que as cenas se encaixam, de modo que os diálogos ganhem sentido.

Para responder as nossas questões de pesquisa, e atender ao objetivo principal deste estudo, focamos a análise dos dados nas interações discursivas entre Silvia e os estudantes na relação com as diferentes ferramentas socioculturais. Para o processo interpretativo, organizamos quadros com o fluxo dessas interações, e neles buscamos analisar a mediação pedagógica de Silvia com base na teoria de Wertsch (1999), explicitando os cinco elementos que a compõem: cena, agentes, ato, propósito e agência. Articulando a teoria da ação mediada e ancorados aos pressupostos do ensino por investigação, buscamos compreender, nos episódios de ensino, como Silvia engajava os estudantes em debates, como promovia a argumentação e como introduzia os estudantes 
em outros procedimentos típicos do "fazer científico" (como elaboração e teste de hipóteses, a construção de modelos explicativos e a construção de consensos na sala de aula para o processo de significação conceitual). Para aumentar a confiabilidade das nossas interpretações, alguns episódios da aula investigada foram discutidos no grupo de pesquisa orientado pelo quarto autor deste artigo.

\section{Resultados e Discussões}

A aula da SEI analisada nesta pesquisa foi divida em três episódios, os quais evidenciaram etapas do desenvolvimento de uma atividade investigativa. No primeiro episódio o propósito de Silvia foi iniciar a construção de um ambiente investigativo para a atividade, ou seja, incentivar os estudantes a problematizar e discutir o que estavam observando. No segundo episódio, Silvia incentivou os alunos a levantar hipóteses e elaborar explicações para o fenômeno. No terceiro e último episódio, os próprios alunos elaboraram uma situação-problema envolvendo o entendimento da função dos componentes do experimento.

\section{Episódio 1}

Os eventos deste episódio ocorreram logo no início da aula. Silvia apresentou o microscópio de gota que, assim como os discursos no decorrer da aula, configuraram-se como ferramentas culturais. O objetivo de Silvia era fomentar o debate e a argumentação, buscando iniciar a construção de um ambiente investigativo. A cena foi o auditório, onde professora e alunos (agentes) investigaram a projeção ampliada da gota de água (ato)(Figura 1).

\begin{tabular}{|l|}
\hline Cena (contexto): auditório. \\
\hline Agentes: professora e alunos. \\
\hline Ato (episódio 1): investigação da ampliação da gota. \\
\hline Propósito (objetivo): estabelecer um ambiente de investigação e debate sobre o experimento. \\
\hline Agência (ferramentas culturais): linguagem (discurso), gestos, experimento do microscópio de gota. \\
\hline $\begin{array}{l}\text { A aula foi iniciada com a projeção do microscópio de gota, e de imediato os alunos notaram a presença } \\
\text { de microrganismos na água. A princípio, os alunos chamaram de micróbios e perguntaram qual } \\
\text { foi o local de coleta da água. Alguns disseram que o fenômeno observado pertencia ao campo da } \\
\text { Física e, em seguida, questionaram os materiais utilizados e a execução da projeção. Os estudantes } \\
\text { elaboraram hipóteses e fizeram inferências sobre a montagem do experimento. Uma delas foi } \\
\text { de que os microrganismos estavam na parede e não na água, e, para testá-la, sugeriram acender } \\
\text { a luz do auditório para tentar vê-los sem o laser. Após o teste, eles refutaram essa hipótese e a } \\
\text { discussão foi conduzida para a problematização da ampliação produzida pelo microscópio de gota. }\end{array}$ \\
\hline
\end{tabular}


1. Professora (P): E como estamos vendo tão grande lá na parede, com um laser e uma seringa com uma gota?

2. A: É um reflexo, tia.

3. A: A água faz aumentar, tia.

4. P: Mas como a água faz aumentar?

5. A: Não sei como tia, mas é ela que aumenta.

6. A: O laser ampliou.

7. A: Tia, pra $[s i c]$ dar certo o laser tem que passar aonde?

8. P: Eu que te pergunto, onde você acha que o laser tem que passar? [alunos realizam inferência]

9. A: Se é a água que aparece lá, o laser tem que passar exatamente no meio da gota, tia, mas é muito difícil.

10. P: Teve gente que falou que a gota ampliou.

11. A: Mas tia, foi o laser ou a gota que ampliou?

12. P: Ótima pergunta, foi o laser ou a gota que ampliou?

13. A: A água.

14. A: O laser.

15. A: Os dois.

16. P: Por que os dois?

17. A: Sozinho o laser não amplia, e sozinha a água também não.

18. P: Se são os dois, como eles juntos ampliam?

19. A: Reflexo.

20. A: Espelho.

21. P: Quando você olha num espelho, o que você vê?

22. A: Eu me vejo.

23. P: Se você se vê, então como ficaria a gota se fosse um espelho?

24. A: Ela não ia passar, e a gente não ia ver na parede.

25. P: Você acha que é um espelho?

26. A: Não, tia.

27. P: Se a luz passa pela gota, como vocês me disseram, o que acontece?

28. A: Quando a luz passa, ela amplia a gota, tia.

Figura 1. Interações discursivas do primeiro episódio

Fonte: dados da pesquisa.

O planejamento da aula previu a utilização do microscópio de gota para a abordagem dos conceitos de lente e refração. Lima, Aguiar Júnior e Caro (2011, p. 865) apoiam o uso de práticas experimentais para a introdução de conceitos científicos afirmando que:

Situações experimentais foram também utilizadas como recurso para se introduzirem 
conceitos. [...] Ao utilizarmos o experimento na introdução de conceitos e modelos científicos, a intenção que temos é a de ir forjando argumentos a partir de evidências que vão sendo apresentadas, de modo a se construir uma explicação científica.

Nessa perspectiva, Hodson (1988) afirma que, sob determinadas circunstâncias, a abordagem experimental permite a observação de eventos que não seriam visíveis no mundo natural, como a visualização de microrganismos em uma gota de água, além de potencializar a obtenção de dados mais detalhados e precisos em relação aos originados em observações passivas. O experimento foi incorporado ao planejamento para servir de elemento mediador entre os agentes, através de interações verbais e manuais, dado que sua manipulação, até certo ponto, era possível. Pereira e Ostermann (2012), reconhecem que a introdução de uma ferramenta cultural nova na ação gera uma espécie de desequilíbrio em sua organização, o que implica em mudanças nos agentes e na mediação como um todo.

Silvia iniciou a aula realizando a ampliação no microscópio de gota, e imediatamente os alunos reagiram com espanto e admiração. Ela apresentou a primeira situação-problema e os alunos elaboraram hipóteses, sendo que na primeira delas (turno 2) o estudante invocou o discurso da ciência, que possui reconhecida autoridade para falar. Wertsch (1999) nos diz que a ação mediada é cercada por forças de autoridade e poder, e que elas podem estar relacionadas com a autoridade de uma comunidade, como a científica.

O aluno afirmou que o que estava sendo visto era um "reflexo" e, apesar de não prosseguir com sua construção, talvez porque a professora tenha dado prioridade à segunda hipótese (turno 3), ele mencionou um termo científico, sem demonstrar, em princípio, uma relação com a ampliação.

A segunda hipótese (turno 3) evidencia uma explicação causal para a ampliação, relacionada à ação da água. Diante da pergunta que a professora fez na intenção de que o aluno desenvolvesse sua explicação, ele afirmou não saber como, mas reforçou em seu enunciado a ideia de que a água era a responsável pelo fenômeno observado. Em seguida, outro aluno atribuiu a ampliação obtida ao laser, mas também sem detalhar a explicação. No turno 7, um aluno propôs uma questão relativa ao procedimento de montagem do experimento, ao problematizar: "Tia, pra [sic] dar certo o laser tem que passar aonde?". A professora o respondeu com outra pergunta, buscando o desenvolvimento da investigação: “Eu que te pergunto, onde você acha que o laser tem que passar?”.

Nesse momento Silvia contribuiu para que o estudante construísse uma inferência, investigando a posição correta do laser para a obtenção da ampliação. Para Hodson (1988), se aprender ciências está relacionado a dar significado ao mundo natural em que se vive, o primeiro passo nesse processo deve ser a familiarização com os fenômenos e eventos a serem compreendidos e explicados, logo, os estudantes devem ver, experimentar e manusear os objetos por si próprios.

Para Wertsch (1999), o experimento é uma ferramenta cultural técnica, dada sua materialidade objetiva como algo que pode ser manipulado. Essa materialidade implica 
em modificações no agente que pode dominar e se apropriar dela, o que também caracteriza a ação mediada. $\mathrm{O}$ mesmo autor destaca que uma ferramenta só pode ser utilizada se houver um agente que saiba operá-la, e salienta a diferença entre domínio e apropriação, que apesar de estarem intimamente relacionados, podem desenvolver-se por processos distintos. Isso corrobora a importância da atitude da professora em promover a realização de inferências, elaboração de hipóteses e comunicação de resultados, pois a linguagem falada constitui-se como uma ferramenta cultural imaterial, e esses aspectos contribuem para o estabelecimento de um ambiente investigativo em sala de aula. Segundo Sasseron (2015), a investigação em aulas de ciências se concretizará quando colocada em prática pelo professor ao promover interações entre: professor, alunos, materiais e informações.

Wertsch (1999) considera que o domínio de uma ferramenta cultural, seja ela material ou imaterial, se relaciona ao poder e à autoridade. Dessa forma, enculturar os estudantes passa por apresentar-lhes as ferramentas da cultura científica e ensinarlhes sobre sua utilização. Nesse cenário de interação prática, dialogicidade e discussão, pode-se entender que a linguagem e o contexto em que ela se desenvolve assumem um papel fundamental no processo de ensino-aprendizagem dos alunos. As interações discursivas propiciam "a oportunidade conferida aos estudantes para a participação nos processos de construção de entendimento, pois, via de regra, se mantém e se sustenta pelas interações discursivas ocorridas ao longo de uma aula" (Sasseron, 2015, p. 60).

$\mathrm{Na}$ sequência, a professora redirecionou a discussão para a ampliação, e foi realizado o questionamento sobre o elemento que a produziu (turnos 10-12). Os alunos elaboraram hipóteses e as comunicaram, sendo que uma delas atribuiu a ampliação ao sistema gota-laser (turno 15). Silvia promoveu o aprofundamento sobre essa hipótese solicitando uma justificativa, mas a resposta dada pelo aluno não apresentou mais detalhes. Então, ela reformulou a questão para a turma (turno 18) e novas hipóteses surgiram. A palavra "reflexo" reapareceu, contudo, mais uma vez desacompanhada de mais detalhes. Porém, um estudante citou o instrumento óptico "espelho", que possui relação com processo de reflexão da luz. Ao perceber que essa ideia estava prevalecendo entre os estudantes, Silvia adotou uma estratégia para conduzi-los a uma contradição. Ela perguntou: “Quando você olha num espelho, o que você vê?", o aluno respondeu: "Eu me vejo". Então, ela formulou a pergunta que levou o aluno a um confrontamento de ideias: "Se você se vê, então como ficaria a gota se fosse um espelho?". O aluno respondeu: "Ela não ia passar, e a gente não ia ver na parede". Silvia perguntou mais uma vez para certifica-se de que a hipótese do espelho havia sido descartada, e a resposta do aluno confirmou isto (turnos 25-26). Esse trecho evidencia a importância da mediação estabelecida na investigação dos resultados do experimento. Silvia utilizou outra ferramenta mediacional para conduzir o estudante no processo de negociação de significados, pois apenas o experimento, que também é uma ferramenta cultural, não determina o processo de forma estática e mecânica, pois, conforme Wertsch (1999), a ferramenta por si só é incapaz de fazer qualquer coisa. Mortimer e Scott (2003) 
reforçam que abordagens de ensino centradas somente em atividades práticas podem ser problemáticas, pois o experimento não fala por si mesmo, ou seja, ele precisa ser mediado pelo professor, que como membro mais experiente da cultura científica, deve mediar o conhecimento a ser ensinado.

O episódio encerrou com Silvia ratificando, através de uma pergunta, a ideia construída com a turma de que a luz precisa atravessar a gota de água. A partir daí, um aluno formulou a seguinte síntese: "Quando a luz passa, ela amplia a gota, tia". A hipótese da reflexão foi levantada, discutida e refutada pelos agentes e nessa etapa da atividade chegaram ao entendimento de que o laser, ao atravessar a gota, produziu a ampliação observada. A professora utilizou esse ponto como fio condutor para conduzir a discussão para a explicação conceitual do fenômeno abordado, que é retratada no episódio a seguir.

\section{Episódio 2}

Neste episódio, Silvia conduziu a discussão para a dimensão conceitual do fenômeno observado, objetivando que os alunos elaborassem hipóteses e explicações causais. $\mathrm{O}$ ato, a cena e os agentes permanecem os mesmos, mas a ferramenta cultural utilizada foi a linguagem, expressa por meio dos discursos e dos gestos. A Figura 2 apresenta os diálogos ocorridos neste episódio.

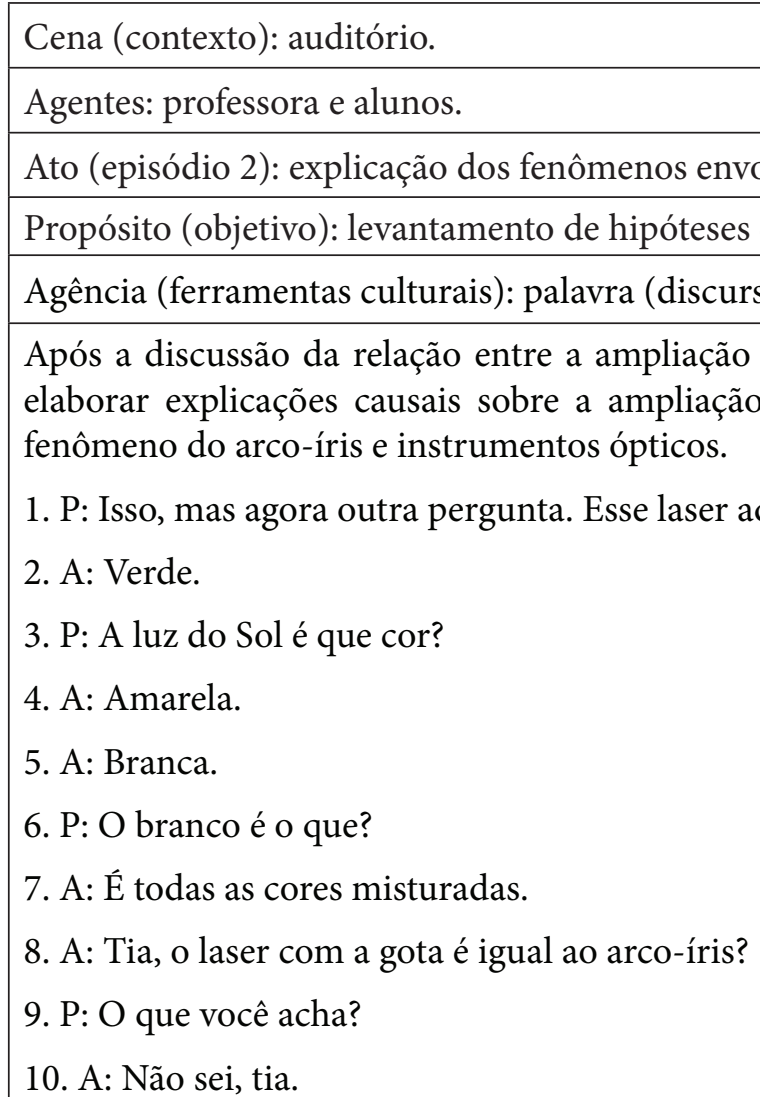

Figura 2. Interações discursivas do segundo episódio (continua) 
11. P: Que dia forma o arco-íris?

12. A: Dia de chuva.

13. A: Dia de Sol.

14. A: Dia de chuva, mas que tem Sol, tia.

15. P: Então o que acontece pra $[$ sic $]$ formar o arco-íris?

16. A: O Sol precisa passar pela chuva, tia.

17. P: E quando ela passa o que acontece?

18. A: Quando a luz passa pela chuva, ela se separa e forma o arco-íris, tia.

19. P: Quando a luz encontra com o espelho, o que acontece?

20. A: Ela reflete.

21. P: E quando ela encontra com a água?

22. A: Ela separa.

23. P: Quando a luz encontra com uma superfície onde ela volta da mesma forma, ela reflete, quando ela encontra um lugar por onde ela passa e se separa, ela refrata.

24. A: Então o laser aparece depois da gota porque ele refratou, tia.

25. P: Mas se ela refratou, porque também ampliou? Trecho inaudível

26. P: Quais são as coisas que vocês conhecem que ampliam as coisas?

27. A: Óculos.

28. A: Microscópio.

29. A: Lupa.

30. P: O que todas essas coisas têm em comum?

31. A: Uma lente

32. A: Tia, a gota é uma lente porque ela é redonda, igual o [sic] óculos da Débora.

33. P: Isso, a gota está funcionando como uma lente. Mas pra [sic] gota funcionar como uma lente e ampliar, ela precisou de que?

34. A: Do laser, foi o laser com a gota que ampliou, tia.

35. P: Agora eu tenho outras perguntas pra vocês. Cada vez que o laser passa pela gota, ele esta ampliando a gota porque a gota é uma...

36. A: Lente!

Figura 2. Interações discursivas do segundo episódio (continuação)

Fonte: dados da pesquisa

Silvia iniciou este episódio com três perguntas do tipo exame (turnos 1, 3 e 6). De acordo com Wertsch (1999), normalmente os discursos dos professores em sala de aula são repletos de perguntas desse tipo, as quais os estudantes devem responder com aquilo que o professor espera ouvir. Ainda segundo esse autor, perguntas do tipo exame pouco 
contribuem para a aprendizagem. Porém, ele alerta que perguntas autênticas, para as quais não se tem uma resposta predeterminada, também não asseguram esse objetivo. Essa postura momentânea de Silvia contrasta com o que foi observado no episódio 1, ou seja, uma mediação marcada por perguntas autênticas. O fato de estar conduzindo o debate para uma dimensão mais conceitual pode ter influenciado as ações de Silvia, que aparentou encaminhar a discussão para uma determinada direção, como será discutido mais adiante.

No turno 8 um aluno pergunta: “Tia, o laser com a gota é igual ao arco-íris?”. Notase aqui a realização de uma contextualização a partir da transposição da observação para um fenômeno observado na natureza. Silvia retomou uma postura dialógica e respondeu ao aluno com outra pergunta, induzindo-o a um aprofundamento (turno 9), mas ele afirmou não saber explicar (turno 10). Ela formulou uma nova questão sobre as condições necessárias para a formação do arco-íris (turno 11), e os estudantes elaboraram hipóteses e debateram sobre elas (turnos 12-14). Silvia retomou a ideia da formação do arco-íris e um aluno disse: "O Sol precisa passar pela chuva, tia". Essa fala evidencia a construção de um modelo explicativo do tipo "realístico" (Grosslight, Unger, Jay, \& Smith, 1991), que é aquele no qual a entidade física corresponde à cópia da realidade concreta. Ou seja, não é a radiação solar que atravessa a gota de água, e sim o próprio Sol que atravessa a chuva. Silvia fez outra pergunta visando o aprofundamento da explicação sobre a formação do arco-íris e um aluno disse: "Quando a luz passa pela chuva, ela se separa e forma o arco- íris, tia”. Nessa fala, o estudante utilizou o termo luz ao invés de Sol, sinalizando uma relação incipiente com ideia de dispersão cromática, embora empregando o termo cotidiano "separa". Logo em seguida, a professora fez outra pergunta, resgatando a discussão sobre espelho e reflexo ocorrida nos turnos 21-27 do episódio 1. Logo depois ela retomou a ideia de dispersão cromática, porém, mais uma vez, sem introduzir o termo científico (turnos 21-22).

O diálogo terminou e Silvia fez uma sistematização (turno 23), introduzindo superficialmente o termo "refrata". Em seguida, um estudante construiu um modelo explicativo empregando o termo recém-apresentado (turno 24), novamente invocando o discurso científico. A professora introduziu outra questão englobando a refração e também a ampliação (turno 25), mas o trecho seguinte ficou inaudível.

Posteriormente, Silvia questionou os estudantes sobre os instrumentos ópticos de ampliação, e eles prontamente citaram os óculos, microscópio e a lupa. Ela perguntou o que esses instrumentos têm em comum, o que resultou na introdução da palavra lente (turno 31), seguida da construção de uma síntese feita por um aluno ao dizer: "Tia, a gota é uma lente porque ela é redonda, igual o [sic] óculos da Débora”. Nessa fala, o estudante afirmou que a gota é uma lente devido ao seu formato esférico e finalizou estabelecendo uma comparação com outro instrumento óptico, os óculos, que também tem seu funcionamento baseado em lentes que podem ser esféricas. Silvia ratificou a construção do aluno repetindo-a para a turma em voz alta (turno 33) e completou seu discurso perguntando sobre outro item que, juntamente com a gota, seria também 
responsável pela ampliação obtida. Prontamente um aluno respondeu: "foi o laser com a gota que ampliou, tia". A professora encerrou o diálogo com uma pergunta do tipo exame (turno 35), reforçando a ideia de que o laser, ao atravessar a gota, promoveu a ampliação, ressaltando a comparação com uma lente.

As duas ideias básicas para o entendimento do experimento do microscópio de gota são: a) a gota de água funciona como uma lente e b) o laser sofre refração ao atravessar a gota de água. As interações discursivas apresentadas no episódio 2 mostram que essas ideias foram, de certa forma, contempladas. Em sua última fala, a professora não retomou o termo refração (turno 35), mas sua mediação conduziu os estudantes à apropriação deste termo, passando pela contextualização do arco-íris, que foi iniciada com a pergunta sobre a cor do laser. Silvia utilizou uma estratégia similar para chegar à ideia de lente, começando com uma pergunta sobre os instrumentos ópticos de ampliação conhecidos pelos estudantes.

No processo interativo de sala de aula, o professor opera com diversas ferramentas culturais como analogias, metáforas, exemplos e contraexemplos. A mediação protagonizada por Silvia sugere que sua intenção era chegar às ideias de refração e lente através de situações cotidianas conhecidas pelos estudantes, no caso, o arco-íris e os instrumentos ópticos comuns (óculos, lupa etc.). Nota-se o esforço da professora em contextualizar e integrar os assuntos, oferecendo meios e recursos para que os alunos conseguissem entender o fenômeno investigado, pois o discurso das ciências é distante da vida cotidiana, o que aponta para a uma necessidade de contextualizar as ideias e exemplificar com aplicações. Na interlocução com Wertsch (1999), baseado nas ideias de Vigotski, compreendemos que os fenômenos humanos só adquirem compreensão ampla quando contextualizados.

Para Vigotski (2009), conceitos com alto grau de generalização são caracterizados por possuírem uma série de outros conceitos articulados entre si. A título de exemplo, podemos citar o conceito de refração, que envolve outros conceitos, tais como meio de propagação, índice de refração e frequência de onda. Podemos dizer que existem diferentes níveis de generalização entre esses conceitos, mas não que há uma hierarquia entre eles.

A aula analisada não objetivava a explicação formal da refração, tampouco a definição precisa de lentes. Isso não seria necessário, pois essas definições podem ser discutidas em outras etapas do processo de escolarização, assim como os outros conceitos correlacionados. Roth (2009) nos ajuda a estabelecer essa argumentação quando diz que apenas "ensinar" os conceitos científicos não garante a aprendizagem dos estudantes, pois não se trata de um processo simples de mudança conceitual. Aprender ciências vai além da apropriação de conceitos. Aprender ciências significa promover uma hibridização das culturas, e, para isso, o professor precisa respeitar a linguagem cotidiana e sua relação com a ciência acadêmica, o que exige o diagnóstico das concepções alternativas para conhecer o modo como os estudantes pensam. O processo de enculturação é lento e envolve negociações e busca de consensos à medida que conhecimentos do senso 
comum e científico dialogam e se relacionam. Assim, não podemos entender um como sendo superior ao outro (Roth, 2009).

A postura da professora permitiu que os estudantes relacionassem elementos de suas vivências cotidianas como base para a emergência de conceitos científicos, os quais se formam em um dado sistema de conceitos que se constitui tradicionalmente dentro de certos parâmetros instituídos pela comunidade científica. Para Mortimer e Scott (2003), conhecer o que os alunos pensam sobre os fenômenos influencia diretamente a aprendizagem posterior de conceitos científicos. Os autores citam atitudes que consideram importantes que o professor assuma como: ouvir e diagnosticar as formas como as atividades são interpretadas pelos estudantes, buscando subsídios para as ações posteriores; auxiliar os alunos a dar sentido ao conhecimento científico e a aplicá-lo no dia-a-dia.

\section{Episódio 3}

Neste episódio retratamos um momento ocorrido na parte final da aula, após a etapa de sistematização realizada por Silvia. Um aluno problematizou um item do experimento e a professora socializou a pergunta, fomentando uma nova investigação (Figura 3).

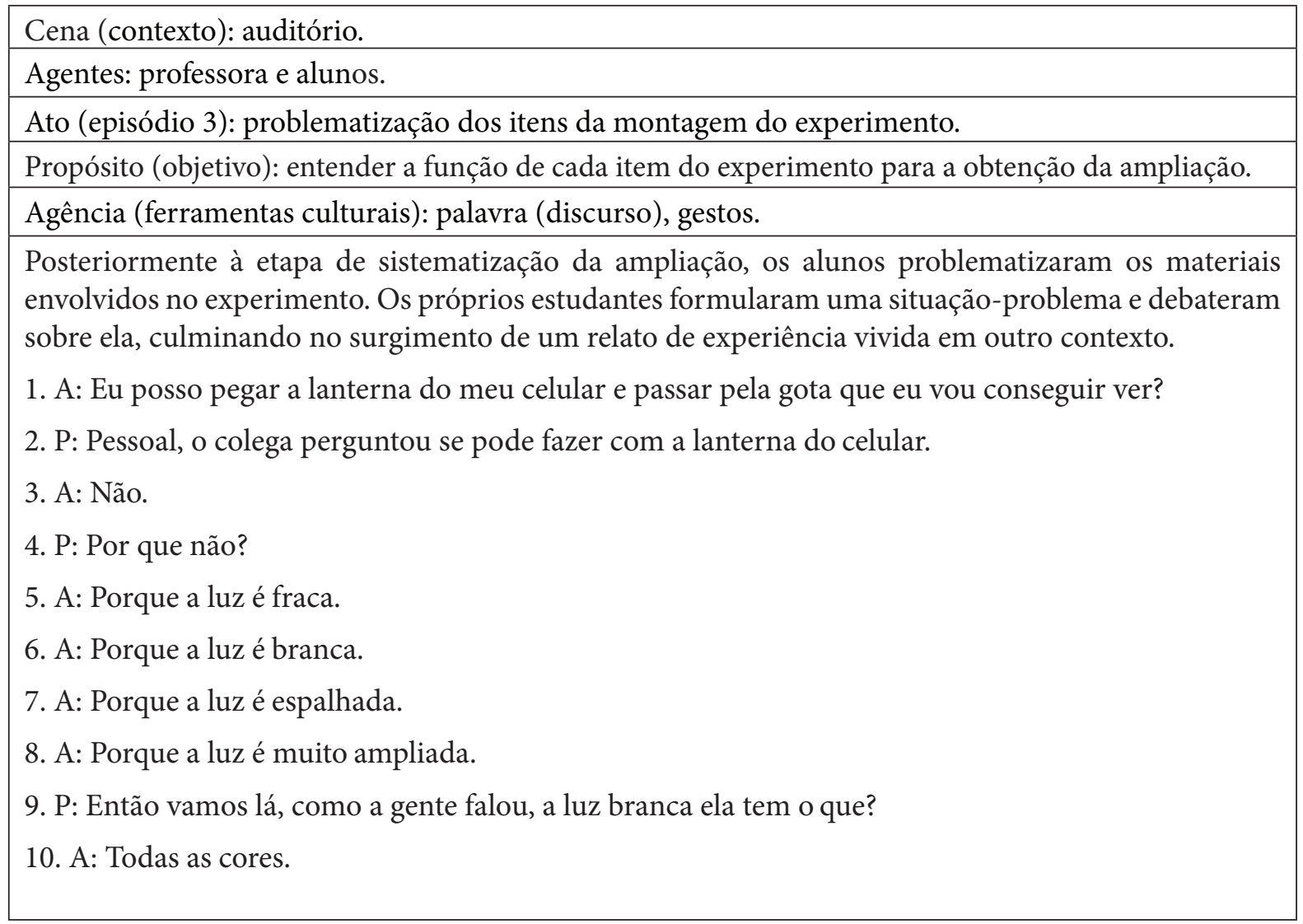

Figura 3. Interações discursivas do terceiro episódio (continua) 
11. P: Outra coisa, além do laser só ter a luz verde, ele sai em um grande espaço ou em um pequeno? 12. A: Em um pequeno.

13. P: Isso, o laser é somente um feixe de luz. Um pontinho. Se a gente tiver uma luz muito grande, como de uma lanterna, e tentar passar pela gota, vai dar certo?

14. A: Não, porque ela não vai passar só no meio da gota.

15. P: Mas e se a gente pegar uma luz branca, num único feixe assim como o laser, o que vai acontecer? 16. A: Aí vai dar.

\section{P: Será?}

18. A: Uma coisa que a gente usou no experimento do meu pai, a gente pegou uma lanterna de celular e tampou com uma fita, deixou só um buraquinho pra $[s i c]$ luz passar, e deu certo, a gente conseguiu ver.

19. P: Agora eu descobri mais uma coisa, a Deise fez com luz branca e deu certo, ela conseguiu ver. Então com a luz branca deu certo, mas com um único feixe, e por que isso?

20. A: Por que a luz precisa passar exatamente no meio da gota.

Figura 5. Interações discursivas do terceiro episódio (continuação)

Fonte: dados da pesquisa.

O episódio começou com um estudante indagando a professora sobre a possibilidade de substituir a fonte de luz do experimento, a caneta laser, por uma lanterna de celular. Ela repetiu a pergunta em voz alta para toda a turma, redirecionando o diálogo e iniciando uma nova investigação. A primeira resposta (turno 3) surgiu desacompanhada de explicações. A professora questionou e os estudantes começaram a elaborar hipóteses para justificar suas ideias. A primeira delas relacionou à intensidade do feixe de luz, pois o aluno disse: "Porque a luz é fraca". Nota-se que o termo "fraca" foi empregado, mas de forma incompatível com o termo cientificamente aceito, o que sugere uma hibridização de termos do discurso científico e do discurso cotidiano (Crepalde, \& Aguiar Júnior, 2013). Pozo e Gómez-Crespo (2009) sinalizam para o fato de que os alunos comumente utilizam de maneira indiferenciada os conceitos de força e energia, como se fossem sinônimos, mesmo após receberem instruções. Nesse sentido, a fala do turno 5 sinaliza para a utilização do termo força de maneira indiferenciada para mais contextos. No turno 6, a fala do aluno resgatou a discussão sobre cores (analisada no episódio 2). Os turnos 7 e 8 indicaram o sentido da colimação do feixe de luz, mas com dois termos da linguagem cotidiana: "espalhada" e "ampliada".

Esse trecho do episódio 3 evidencia a manipulação mental de variáveis e a construção de argumentos entre os sujeitos engajados na busca pelo entendimento, em que eles dialogam sobre validar, aceitar e refutar hipóteses relativas ao processo de investigação, que constitui o processo de interação discursiva em aulas de ciências da natureza. É importante refletir que a discussão poderia nem ter ocorrido caso a professora simplesmente respondesse a pergunta feita pelo aluno. Este aspecto sinaliza para a 
importância da mediação intencional no estabelecimento de um ambiente propício a investigações, no qual os estudantes consideraram que podiam propor um problema a ser investigado, o que evidencia engajamento e imersão nesse ambiente.

A partir da argumentação dos estudantes, Silvia iniciou uma sistematização (turno 9), começando pela retomada da discussão de cores retratada no episódio 2. Em seguida, ela abordou a questão da colimação do feixe (turnos 11 e 13), mas sem introduzir o termo científico, por tratar-se de um conceito complexo, cuja discussão extrapolaria os objetivos da intervenção. A dificuldade na abordagem de conceitos relativos aos temas ótica e ondas foi apontada por Paganotti e Dickman (2011) em um estudo envolvendo professores que trabalham tópicos de Física no ensino fundamental. Esses temas foram incluídos dentre os mais difíceis para ensinar por serem abstratos e de difícil compreensão por parte dos alunos.

Silvia prosseguiu com o diálogo e fez um novo questionamento para a turma (turno 15), envolvendo uma nova configuração para o experimento do microscópio de gota. Um estudante respondeu positivamente e ela o questionou em seguida (turnos 16-17), sugerindo esperar uma resposta diferente. Nesse momento, uma aluna relatou uma experiência vivenciada fora do espaço escolar (turno 18), na qual ela e o pai reproduziram o experimento de forma similar à proposta pela professora, e afirmou que o resultado positivo foi obtido. Silvia socializou em voz alta o relato da estudante para que toda a turma pudesse participar da discussão (turno 19), e introduziu no seu discurso a ideia de feixe colimado, porém, mais uma vez sem mencionar o termo. $\mathrm{O}$ relato da aluna parece concordar com a afirmação de Driver, Asoko, Leach, Mortimer e Scott (1999), sobre os estudantes chegarem à escola com representações construídas, comunicadas e validadas na cultura do dia-a-dia.

Wertsch (1999) considera importantíssimo que o professor auxilie o aluno a fazer/elaborar perguntas autênticas, que o ajude a pensar e refletir sobre os conteúdos abordados.

Dos 20 turnos transcritos neste episódio, apenas oito mostram falas da professora, o que indica o protagonismo dos estudantes na discussão. Eles criaram novos problemas na sala de aula, elaboraram hipóteses, estabeleceram relações com experiências vividas em outros contextos e chegaram a uma conclusão, ou seja, percorreram todo o caminho de uma autêntica investigação, tudo isso sob a supervisão de Silvia, que realizou intervenções pontuais, redirecionando as perguntas e auxiliando na sistematização.

\section{Conclusões e Implicações}

A ação mediada, intencional e organizada realizada pela professora foi essencial para a promoção de um ambiente investigativo em sala de aula. Por meio da mediação da professora, os estudantes tiveram uma experiência de investigação que pode ser considerada autêntica, uma vez que puderam debater sobre um fenômeno observado através do experimento e também investigar uma situação-problema proposta por um dos alunos. As interações discursivas retratadas nos três episódios mostram diversos 
elementos que nos permite entender que a aula caracterizou-se como sendo investigativa. Isso porque os estudantes elaboraram e testaram hipóteses, argumentaram, debateram, realizaram inferências e registraram suas conclusões por meio de desenhos.

Segundo Sasseron $(2015$, p. 64), quando a mediação promove "condições para que os estudantes trabalhem ativa e conjuntamente na resolução de um problema, novas perguntas vão se construindo e se transformando em novas avaliações". Esses elementos podem ser vistos no terceiro episódio analisado, em que os alunos realizaram uma nova investigação a partir de uma situação-problema criada por um dos estudantes, o que evidencia o caráter propício a investigações e trocas verbais do ambiente estabelecido pela professora. Promover um ambiente no qual os alunos sintam que podem perguntar, investigar - e até realizar suas próprias investigações - não é um resultado trivial. Ferraz e Sasseron (2017) afirmam que, mesmo que a mediação estabelecida seja adequada à criação de um ambiente investigativo e a dialogicidade, sua inter-relação com outros fatores da cultura escolar e das interações entre os sujeitos da sala de aula pode interferir nesse processo.

Ao caracterizar a mediação estabelecida por Silvia com base na teoria de Wertsch, evidenciamos o uso de algumas estratégias adotadas pela docente, como: responder perguntas com outras perguntas, redirecionar as hipóteses e questões levantadas por um aluno à turma e o predomínio de perguntas autênticas. Com relação à atividade investigativa, constatamos que a mediação foi imprescindível para que a manipulação do experimento não se tornasse meramente mecânica e os conceitos descontextualizados, haja vista que é a compreensão teórica que dá propósito e significado aos experimentos. Além disso, as interações discursivas mostram que os alunos invocaram o discurso da ciência, empregando-o juntamente com alguns termos de uso cotidiano nos momentos de argumentação e contra-argumentação, indo além da comunicação de resultados. Evidenciamos que os estudantes expressaram suas ideias e pensamentos, argumentaram e contra-argumentaram, mostrando-se engajados no processo de construção do conhecimento.

Outro apontamento importante é que, apesar de a professora não ter introduzido os termos científicos "colimação" e "dispersão cromática", o significado desses conceitos foi contemplado durante a aula através da problematização e da investigação motivadas pelo experimento.

Apesar de ainda estar no curso de formação inicial e não ter a formação específica na área de Física, a licencianda não deixou de abordar os conceitos de Ótica, conduzindo atividades que permitiram aos estudantes a contextualização dos conceitos de refração e lentes, relacionando-os ao fenômeno do arco-íris e dos instrumentos óticos que podem produzir ampliação, como lupa e óculos.

Com base nas ideias de Vigotski, Facci (2010) discute que é comum que, ao se depararem com um novo conceito, as crianças busquem seu significado por meio de uma relação que o aproxime de um conceito já internalizado por elas. Nessa perspectiva, a autora afirma que "o desenvolvimento do conceito científico deve apoiar-se em um 
conceito espontâneo já apropriado pelo indivíduo e este não pode ser indiferente à formação daquele conceito" (Facci, 2010, p. 135). Consideramos que a contextualização dos conceitos contribuiu para ampliar o entendimento dos alunos, pois suas falas sugeriram uma compreensão da relação entre o fenômeno observado e as vivências pessoais citadas por eles durante o desenvolvimento da aula. Os estudantes possuem um repertório de experiências e conhecimentos adquiridos socialmente que, embora muitas vezes divirjam do entendimento estrito da comunidade científica, quase sempre contribuem para a atribuição de sentidos e significados a esses conceitos.

Os resultados aqui apresentados corroboram o entendimento de que ao assumir a Educação em Ciências como meio difusor do processo de enculturação, reconhecemos a sua relevância no sentido de garantir a democratização do acesso aos conhecimentos científicos e, ao fazê-lo, propiciar ao estudante a oportunidade de inserção no modo de pensar e fazer ciência, que é próprio da cultura científica.

O estudo reafirma a pertinência da implementação de ações educativas pautadas nos princípios teórico-metodológicos do ensino por investigação na perspectiva da ação mediada. Esta abordagem torna-se ainda mais relevante e significativa quando desenvolvida no contexto específico da formação de professores de Ciências, de modo a proporcionar ao futuro professor a autonomia e o protagonismo na proposição de intervenções pedagógicas inovadoras.

\section{Referências}

Aikenhead, G. (2009). Educação Científica para todos. Lisboa: Edições Pedagogo.

Aguiar Júnior, O. G., \& Lima, M. E. C. C. (1999). Professores de Ciências, a Física e a Química no Ensino Fundamental. In II Encontro Nacional de Pesquisa em Educação em Ciências, 1999, Valinhos, SP. Anais do II Encontro Nacional de Pesquisa em Educação em Ciências (cdrom). 1, (p. 1-15).

Azevedo, M. C. P. S. (2004). Ensino por investigação: problematizando as atividades em sala de aula. In Carvalho, A. M. P. (Org.), Ensino de ciências: unindo a pesquisa e a prática (pp.19-33). São Paulo, SP: Pioneira Thomson Learning.

Barrow, L. H. (2006). A Brief History of Inquiry: From Dewey to Standards. Journal of Science Teacher Education, 17, 265-278, Springer 2006. https://doi.org/10.1007/s10972006-9008-5.

Bertagna-Rocha, M. (2013). A formação dos saberes sobre Ciências e seu ensino: trajetórias de professoras dos anos iniciais do Ensino Fundamental. (Tese de doutorado). UNICAMP, São Paulo.

Borges, A. T. (2002). Novos rumos para o laboratório escolar de ciências. Caderno Brasileiro de Ensino de Física, 19(3), 291-313. 
Carvalho, A. M. P. (2004). Metodologia de pesquisa em ensino de física: uma proposta para estudar os processos de ensino e aprendizagem. In Anais do IX Encontro de Pesquisa em Ensino de Física (cdrom), ( pp. 1-12). Jaboticatubas, MG.

Carvalho, A. M. P. (2013). O ensino de ciências e a proposição de sequências de ensino investigativas. In A. M. P. Carvalho (Org.) Ensino de Ciências por investigação: Condições para implementação em sala de aula (pp. 1-20). São Paulo: Cengage Learning.

Carvalho, A. M. P. (2018). Fundamentos Teóricos e Metodológicos do Ensino por Investigação. Revista Brasileira de Pesquisa em Educação em Ciências, 18(3), p. 765-794. https://doi.org/10.28976/1984-2686rbpec2018183765

Carvalho, A. M. P., Garrido, E., Laburu, C. E., Moura, M. O., Santos, M., Silva, D.,Abib, M. L. V. S., Castro, R. S., Itacarambi, R. R., \& Gonçalves, M. E. R. (1993). A história da ciência, a psicogênese e a resolução de problemas na construção do conhecimento em sala de aula. Revista da Faculdade de Educação (USP). 19(2), 245-256.

Carvalho, A. M. P., \& Gil-Perez, D. (2011). Formação de Professores de Ciências: Tendências e Inovações. 10. ed. São Paulo: Cortez Editora.

Crepalde, R. S., \& Aguiar Júnior, O. G. (2013). A formação de conceitos como ascensão do abstrato ao concreto: da energia pensada à energia vivida. Investigações em Ensino de Ciências, Porto Alegre, 18(2), 299-325.

Cunha, A. M. O., \& Krasilchik, M. (2000). A formação continuada de professores de Ciências: percepções a partir de uma experiência. In 23a Reunião da Associação Nacional de Pós Graduação e Pesquisa em Educação, 2000, Caxambú. Educação não é privilégio Anais em CD-ROM.

Damiani, M. F. (2012). Sobre Pesquisas do Tipo Intervenção - Painel: As Pesquisas do Tipo Intervenção e sua Importância para a Produção de Teoria Educacional InAnais do XVI Encontro Nacional de Didática e Prática de Ensino. Campinas: UNICAMP. p. 1-9.

Damiani, M. F., Rochefort, R. S., Castro, R. F., Dariz, M. R., \& Pinheiro, S. N. S. (2013). Discutindo pesquisas do tipo intervenção pedagógica. Cadernos de Educação (UFPel), 45, 57-67.

Driver, R., Asoko, H., Leach, J., Mortimer, E. F., \& Scott, P. (1999). Construindo conhecimento científico em sala de aula. Química Nova na Escola, São Paulo, 9(31), $31-40$.

Duschl, R. A. (1994). Research on the history and philosophy of science. In D. Gabel. Handbook of research on science teaching and learning. (pp. 443-465) New York: MacMillan Publishing Company. 
Facci, M. G. D. (2010). Vigotski e o processo ensino-aprendizagem: a formação de conceitos. In S. G. de L., Mendonça, \& S. Miller (Org.). Vigotski e a Escola Atual: fundamentos teóricos e implicações pedagógicas. (pp. 123-148). Araraquara: Junqueira \& Marin Editores.

Ferraz, A. T., \& Sasseron, L. H. (2017). Propósitos epistêmicos para a promoção da argumentação em aulas investigativas. Investigações em ensino de ciências, 22(1). https:// doi.org/10.22600/1518-8795.ienci2017v22n1p42

Grosslight, L., Unger, C., Jay, E., \& Smith, C. (1991). Understanding models and their use in science: conceptions of middle and high school students and experts. Journal of Research in Science Teaching, 28(9). 799-822.

Hodson, D. (1988). Experiments in Science and Science Teaching, Educational Philosophy and Theory. 20(2), 53-66.

Lima, M. E. C. C., Aguiar Junior, O., \& Caro, C. M. (2011). A formação de conceitos científicos: reflexões a partir da produção de livros didáticos. Ciência \& Educação, 17(4), 855-871. https://doi.org/10.1590/S1516-73132011000400006

Lima, M. E. C. C., Martins, C. M. D. C., \& Paula, H. De F. (Orgs.). (2009). Ensino de ciências por investigação-ENCI. Vol. III. Belo Horizonte: UFMG/FAE/CECIMIG.

Lüdke, M., Cruz, G. B. D., \& Boing, L. A. (2009). A pesquisa do professor da educação básica em questão. Revista Brasileira de Educação, 14(42), 456-602.

Mortimer, E. F., \& Scott, P. (2003). Meaning making in secondary science classrooms. Maidenhead, Philadelphia: Open University Press.

Paganotti, A., \& Dickman, A. G. (2011). Caracterizando o professor de ciências: quem ensina tópicos de física no ensino fundamental? In XIX Simpósio Nacional de Ensino de Física, Manaus AM.

Pereira, A. P., \& Ostermann, F. (2012). A aproximação sociocultural à mente, de James V. Wertsch, e implicações para a educação em ciências. Ciência e Educação (UNESP. Impresso), 18(1), 23-39.

Pozo, J. I., \& Gómez-Crespo, M. A. G. (2009). A aprendizagem e o ensino de ciências: do conhecimento cotidiano ao conhecimento científico. 5. ed. Porto Alegre: Artmed.

Robson, C. (1993). Real World Research. Oxford: Blackwell.

Roth, W. M. (2009). Taking a stand (point): introduction to a science (education) from people for people. In W. M., Roth, (Ed.). Science education from people for people: taking a stand (point). London, New York: Routledge.

Sá, E. F. de. Paula, H. de F., Lima, M. E. C., \& Aguiar, O. G. de. (2007). As características das atividades investigativas segundo tutores e coordenadores de um curso de especialização em ensino de ciências. In Encontro Nacional de Pesquisa em Ensino de Ciências, 6, Florianópolis, SC. 
Sasseron, L. H. (2013). Interações discursivas e investigação em sala de aula: o papel do professor. In A. M. P. de, Carvalho (org.). Ensino de Ciências por Investigação: Condições para Implementação em Sala de Aula. São Paulo: Cengage Learning (pp. 41-61).

Sasseron, L. H. (2015). Alfabetização Científica, Ensino por Investigação e Argumentação: relações entre ciências da natureza e escola. Ensaio: Pesquisa em Educação em Ciências, 17(especial), 49-67. http://dx.doi.org/10.1590/1983-2117201517s04

Sasseron, L. H. (2018). Ensino de Ciências por Investigação e o Desenvolvimento de Práticas: Uma Mirada para a Base Nacional Comum Curricular. Revista Brasileira de Pesquisa em Educação em Ciências, 18(3), 1061-1085. http://dx.doi.org/10.28976/19842686rbpec20181831061

Schroeder, C. (2004). Um currículo de física para as primeirasséries do ensino fundamental. (Dissertação de Mestrado) Instituto de Física, Universidade Federal do Rio Grande do Sul, Porto Alegre.

Trazzi, P. S. S., \& Oliveira, I. M. (2016). A ação mediada no processo de formação dos conceitos científicos de fotossíntese e respiração celular em aulas de biologia. Investigações em Ensino de Ciências, 21(2), 121-136.

Trivelato, S. L. F., \& Tonidandel, S. M. R. (2015) Ensino por investigação: eixos organizadores para sequências de Ensino de Biologia. Ensaio: Pesquisa em Educação em Ciências, 7(especial), 97-114.

Vigotski, L. S. (2009). A construção do pensamento e da linguagem. São Paulo, SP: Martins Fontes.

Wertsch, J. V. (1999). La mente enacción. Buenos Aires, AR: Aique. 


\section{Leandro da Silva Barcellos}

${ }^{\circ}$ https://orcid.org/0000-0002-8912-3052 Universidade Federal do Espírito Santo Departamento de Teorias e Práticas de Ensino Vitória, Espírito Santo, Brasil leandrobarcellos5@gmail.com

\section{Suiany Vitorino Gervásio}

(1) https://orcid.org/0000-0003-3594-2922 Universidade Federal do Espírito Santo Vitória, Espírito Santo, Brasil suianygervasio@gmail.com

Mirian do Amaral Jonis Silva

${ }^{\circledR}$ https://orcid.org/0000-0002-3838-8798 Universidade Federal do Espírito Santo Departamento de Teorias e Práticas de Ensino Vitória, Espírito Santo, Brasil mirianjonis67@gmail.com

Geide Rosa Coelho

${ }^{\circledR}$ https://orcid.org/0000-0001-5358-9742 Universidade Federal do Espírito Santo Departamento de Teorias e Práticas de Ensino Vitória, Espírito Santo, Brasil geidecoelho@gmail.com

Submetido em 08 de Junho de 2018 Aceito em 28 de Novembro de 2018 Publicado em 02 de Maio de 2019 